\title{
Indirect Measurement of Effective Throat Thickness in T-joint Weld by Ultrasonic Method Phased Array
}

Radoslav Konar ${ }^{1}$, Michal Sventek ${ }^{2}$, Miroslav Bucha ${ }^{3}$

${ }^{1}$ Department of Technological Engineering, Faculty of Mechanical Engineering, University of Zilina, Univerzitna 8215/1, 01026 Zilina. Slovak Republic. E-mail: radoslav.konar@fstroj.uniza.sk,

${ }^{2}$ MONT IRP s.r.o., Oceliarska 2, 01001 Zilina, Slovak Republic. E-mail: msventek@ montirp.com

${ }^{3}$ SPP-distribucia, a.s., Levicka 9, 95054 Nitra, Slovak Republic. E-mail: miroslav.bucha@spp-distribucia.sk

The article deals with non-destructive measurement of the effective throat thickness of fillet weld with deep penetration in T-joint. Ultrasonic Phased Array technology is used to indirectly measurement of effective weld throat thickness. Phased Array ultrasonic systems utilise multi-element probes, which are individually excited under computer control. By exciting each element in a controlled manner, a focused beam of ultrasound can be generated. Software enables the beam to be steered. Two and three dimensional views can be generated showing the sizes and locations of any flaws detected. The results of Phased Array ultrasonic measurements are compared with the real results obtained from the real macrostructural analysis. The methodology is appropriate for verifying compliance with the design weld throat thickness in the production of steel structures.

Keywords: Ultrasonic testing, T-joint, Phased Array

\section{Acknowledgement}

This work has been supported by the Scientific Grant Agency of the Ministry of Education of the Slovak Republic, grant VEGA: 1/0836/13, KEGA: 034ZU-4/2015 and KEGA: 014ZU-4/2015.

\section{References}

[1] LANGENBERG, K., J., MARKLEIN, R., MAYER, K. (2012). Ultrasonic nondestructive testing of materials Theoretical foundations. pp. 772. CRC Press, New York.

[2] KOPEC, B. et al.: Nondestructive Testing of Materials and Structures, CERM, s.r.o. : Brno, 2008, p. 573, ISBN 978-80-7204-591-4.

[3] MEŠKO, J., ZRAK, A., MULCZYK, K., TOFIL, S. (2014). Microstructure analysis of welded joints after laser welding. In: Manufacturing technology, Vol. 14, No. 3, pp. 355-359. J.E. Purkyne University, Ústi nad Labem.

[4] RADEK, N., MEŠKO, J., ZRAK, A. (2014). Technology of laser forming. In: Manufacturing technology, Vol. 14, No. 3, pp. 428-431. J.E. Purkyne University, Ústi nad Labem.

[5] MICIAN, M., PATEK, M., SLADEK, G. (2014). Concept of Reapiring Branch Pipes on High-pressure Pipelines by Using split Sleeve. In: Manufacturing technology, Vol. 14, No. 3, pp. 60-66. J.E. Purkyne University, Ústi nad Labem.

[6] DOPJERA, D., MICIAN, M. (2014). The Detection of Artificially Made Defects in Welded Joint with Ultrasonic defectoscopy Phased Array. In: Manufacturing technology, Vol. 14, No. 1, pp. 12-17. J.E. Purkyne University, Ústi nad Labem.

[7] VRZGULA, P., FATURÍK, M., MICIAN, M. (2014). New Inspection Technologies for Identification of Failure in the Materials and Welded Joints for Area of Gas Industry. In: Manufacturing technology, Vol. 14, No. 3, pp. 487-492. J.E. Purkyne University, Ústi nad Labem.

[8] MORAVEC, J., BRADAC, J., NOVAKOVA, I. (2014) Ways of numerical prediction of austenitic grain size in heat-affected zone of welds. In: 7th International Conference on Innovative Technologies for Joining Advanced Materials, TIMA 2014, Trans Tech Publications Ltd.

[9] KONAR, R., MICIAN, M. (2014). Non-destructive testing of welds in gas pipelines repairs with Phased Array ultrasonic technique. In: Manufacturing technology, Vol. 14, No. 1, pp. 42-47. J.E. Purkyne University, Ústi nad Labem.

[10]OLYMPUS (2013). The company Olympus NDT. Online: 〈http://www.olympus-ims.com/cs〉. 